\title{
MODERNITY VS. POSTMODERNITY: ASSESSING THE DESIGN QUALITY OF URBAN PARKS BY AHP
}

\author{
Assoc. Prof. Elif KUTAY KARAÇOR* \\ Ress Asst Kiymet UZUN YÜKSEL* * \\ Ress Asst Berfin ȘENIK** *
}

\begin{abstract}
The perceptual design quality of physical spaces has been increasingly studied in the literature in recent years. However, the studies in the field of landscape architecture are insufficient about how the design quality of urban parks built in different periods is perceived today. This study aims to compare urban parks that reflect modern and postmodern designs in terms of design quality criteria. In this context, 4 subjective design quality criteria (imageability, legibility, vitality, diversity) were evaluated for Prospect Park and Parc des Buttes-Chaumont modern period parks, and Millennium Park and Parc de la Villette postmodern period parks. Expert opinion was consulted in design criteria and selection of city parks. Analytic Hierarchy Process was used to compare modern and postmodern period parks and Expert Choice software was used. In this study, 4 urban parks were defined as alternatives and 4 design qualities were defined as criteria. The results revealed that the designs of the city parks reflect the postmodern design line that perceived with higher quality. Besides, the most prominent criterion among the design criteria was found as Imageability. This study makes a perceptual contribution to the comparison of the design quality of urban parks of different periods.
\end{abstract}

Keywords: Perceptual Design Quality, Modern Parks, Postmodern Parks, AHP.

Received Date: 12.03.2020 Accepted Date: 06.11.2020 Arcticle Types: Research Article

\footnotetext{
*Duzce University, Forestry Faculty, Landscape Architecture Department, 81620 Yörük/Düzce Merkez/Düzce, elifkaracor@yahoo.com, ORCID: 0000-0001-9636-1406

**Duzce University, Forestry Faculty, Landscape Architecture Department, 81620 Yörük/Düzce Merkez/Düzce, kiymetuzun@duzce.edu.tr ORCID: 0000-0001-9754-7552

***Duzce University, Forestry Faculty, Landscape Architecture Department, 81620 Yörük/Düzce Merkez/Düzce, berfinsenik@duzce.edu.tr ORCID: 0000-0001-8988-7100
} 


\title{
MODERNITEYE KARȘIT POSTMODERNITE: KENT PARKLARININ TASARIM KALITESININ AHS ILE DEĞERLENDIRILMESI
}

\author{
Doç. Dr. Elif KUTAY KARACOR* \\ Arș. Grv. Kıymet UZUN YÜKSEL* * \\ Arș. Grv. Berfin ȘENIK****
}

Özet: Fiziksel mekanların algısal tasarım kalitesi son yıllarda literatürde giderek daha fazla çalışılmaktadır. Ancak, farklı dönemlerde inşa edilen kent parklarının tasarım kalitesinin bugün nasıl algılandığı konusunda peyzaj mimarlığı alanındaki çalışmalar yetersiz kalmaktadır. Bu çalışma, modern ve postmodern tasarımları yansıtan kentsel parkları tasarım kalite kriterleri açısından karşılaştırmayı amaçlamaktadır. Bu bağlamda, Prospect Park ve Parc des Buttes-Chaumont modern dönem parkları ile Millennium Park ve Parc de la Villette postmodern dönem parkları için 4 sübjektif tasarım kalite kriteri (imgelenebilirlik, okunabilirlik, canlılık, çeşitlilik) değerlendirilmiştir. Tasarım kriterlerinin ve kent parklarının seçiminde uzman görüşüne başvurulmuştur. Modern ve postmodern dönem parklarını karşılaştırmak için Analitik Hiyerarşi Süreci’ne başvurulmuş ve Expert Choice yazılımı kullanılmıştır. $\mathrm{Bu}$ çalışmada 4 kent parkı alternatif, 4 tasarım kalitesi ise kriter olarak tanımlanmıştır. Elde edilen bulgular, postmodern tasarım çizgisini yansıtan kent parklarının daha yüksek kaliteli algılandığını ortaya koymuştur. Ayrıca, tasarım kriterleri arasında en fazla öne çıkan kriter “imgelenebilirlik" olarak bulunmuştur. Bu çalışma, farklı dönemlerdeki kent parklarının tasarım kalitesinin karşılaştırılmasına algısal açıdan katkı sağlamaktadır.

Anahtar Kelimeler: Algısal Tasarım Kalitesi, Modern Parklar, Postmodern Parklar, AHS.

Geliş Tarihi: 12.03.2020 Kabul Tarihi: 06.11.2020 Makale Türü: Araştırma Makalesi

*Düzce Üniversitesi, Orman Fakültesi, Peyzaj Mimarlığı Bölümü, 81620 Yörük/Düzce Merkez/Düzce, elifkaracor@yahoo.com, ORCID: 0000-0001-9636-1406

**Düzce Üniversitesi, Orman Fakültesi, Peyzaj Mimarlı̆̆ı Bölümü, 81620 Yörük/Düzce Merkez/Düzce, kiymetuzun@duzce.edu.tr ORCID: 0000-0001-9754-7552

***Düzce Üniversitesi, Orman Fakültesi, Peyzaj Mimarlı̆̆ı Bölümü, 81620 Yörük/Düzce Merkez/Düzce, berfinsenik@duzce.edu.tr ORCID: $0000-0001-8988-7100$ 


\section{INTRODUCTION}

The "quality" can be defined as "congruity to the desired criteria," "level of the product or service in meeting the needs of consumers" or "congruity to the usage, the need". Several concepts like liveability, quality of life, sustainability in different academic disciplines (psychology, sociology, environmental sciences, economics, etc.) and in the areas of specialization (planning, architecture, landscape architecture, engineering, health, etc.,) are judged by the criteria of "quality" (Aydin and Ter, 2008). The studies on the design quality of physical spaces have increased in recent years. The main reason for this increase in perceptual quality studies is the user-oriented approaches together with individual differences and personal tastes which are taken into account for the design of physical space in the 21 st century. Several studies have been done on the quality of the physical environment such as urban design quality (Ewing et al., 2006), neighborhood design quality (Karaçor et al., 2019), urban space quality (Inceoğlu ve Aytuğ, 2009), open space quality (Sugiyama et al., 2015; Taylor et al., 2011), and public parks quality (Barrett et al., 2011). However, there are deficiencies in the physical environment studies in terms of comparing the design quality of urban parks from different periods. The aim of this study is to determine which design quality criteria come to the forefront in urban parks designed and built in the modern and postmodern period. In this study, 4 subjective design criteria (imageability, legibility, vitality, diversity) were applied to both modern period parks (Prospect Park, Parc des Buttes-Chaumont) and postmodern period parks (Millenium Park, Parc de la Villette).

\section{DESIGN QUALITY OF URBAN PARKS}

There are many perceptual quality criteria in the literature. However, the measurement and evaluation of these criteria have several advantages and disadvantages according to the method of the study and type of physical space such as being public space, open space, street, neighborhood. In the scope of this study, 4 quality criteria that could be applied to urban parks were chosen by the expert view. 51 perceptual quality criteria derived from different fields by Ewing et al (2006) were presented to experts in this study, then those criteria that can be used in the evaluation of urban parks were chosen by four experts with a consensus. The definitions of these quality criteria are given in Table 1.

\begin{tabular}{|c|c|}
\hline Imageability & $\begin{array}{c}\text { Imageability can be defined as the quality in a physical object } \\
\text { which evokes a strong image in any observer (Lynch, 1960). }\end{array}$ \\
\hline Legibility & $\begin{array}{c}\text { Legibility means the possibility of recognizing and organizing } \\
\text { an environment within an imageable and coherent pattern (Koseoglu } \\
\text { ve Onder, 2011). }\end{array}$ \\
\hline Vitality & $\begin{array}{l}\text { Vitality refers to the numbers of people in and around any place } \\
\text { (pedestrian flows) across different times of the day and night, the } \\
\text { uptake of facilities, the number of cultural events and celebrations } \\
\text { over the year, and generally the extent to which a place feels alive } \\
\text { (Montgomery, 1998). }\end{array}$ \\
\hline Diversity & $\begin{array}{l}\text { The term diversity has a variety of meanings in urban literature. } \\
\text { planners, it may mean mixed uses or class and racial-ethnic } \\
\text { heterogeneity (Fainstein, 2005). It can be evaluated by landscape } \\
\text { architects as cultural heterogenity of green space users (Ozyavuz and } \\
\text { Korkut, 2006) and natural and cultural variety in recreation areas. }\end{array}$ \\
\hline
\end{tabular}

Table 1. Definitions of perceptual qualities. 


\begin{tabular}{|l|l|}
\hline Modern Parks & Post Modern Parks \\
\hline Prospect Park-USA & Millenium Park-USA \\
\hline $\begin{array}{l}\text { Parc des Buttes-Chaumont- } \\
\text { France }\end{array}$ & Parc de la Villette-France \\
\hline
\end{tabular}

Table 2. Study Areas.

\section{STUDY AREAS}

The selection of parks has gained importance for his study to compare the parks designed and built in the modern and post-modern periods. For this reason, the parks were selected from high recognized ones that having the characteristics and functions of urban parks, and clearly reflecting the line of the period. In this scope, 4 urban parks were selected as 2 modern parks and 2 postmodern parks after the selection of design criteria by the expert view. The expert panel was composed of 4 landscape architects. To make objective comparisons between modern and postmodern parks, it was ensured that both countries (US-France) parks were included in both periods. In addition to the period in which these parks were selected, their size, equipment and location in the city were also taken into account. The selected parks and their periods are given in Table 2.

\subsection{Prospect Park-USA}

Prospect Park is a large urban park: an oasis in the heart of Brooklyn, NY. Designed by Frederick Law Olmsted and Calvert Vaux in 1868 (Toth, 1995), Prospect Park covers 160.4 hectares (Lancaster,1972), including 76 hectares of remnant and replanted woodlands, which were present before the park's construction (Toth, 1995). Currently, Prospect Park experiences over 10 million annual visits (Prospect Park Alliance, 2013).

It is difficult to imagine Manhattan without its
Central Park, Brooklyn without its Prospect Park, or other urban imitators of the former without major parks at the very heart of their urban core. But in the mid 19th century the creation of these masterpieces of landscape architecture depended upon the concerted lobbying effort of numerous individuals over long periods before and throughout their design and construction (Patton \& Menke, 1982). The park's contrast with the overall cityscape was recapitulated by the processional character of the park which brought visitors to and from scenes of the city. Prospect Park was divided into three distinct natural landscapes. Open fields of trimmed greensward, stretching over a distance of a mile uninterrupted by carriage roads, gave one section of the park a pastoral character (Bluestone, 1987).

\subsection{Parc des Buttes-Chaumont-France}

The Parc des Buttes-Chaumont engages with a long tradition of public parks in France and the west more generally. At its most basic, it forms part of the nineteenth-century critique of symmetrically organized gardens embodied in France in the parks of the Ancien Regime and Andre Le Notre in particular through the incorporation of the Victorian model of urban 'landscape' gardens, or public parks, into the French canon from the 1830s onward (Strohmayer, 2006).

The Parc des Buttes-Chaumont is one of the oldest and largest parks in Paris and was envisioned as a garden showcase when established in 1867(Muratet et al., 2015). The 
engineer and landscape designer Jean Charles Adolphe Alphand (1817-91) was the Chief Engineer of Parks. His transformation of an infamous quarry site into the celebrated Parc des Buttes Chaumont (1867) was the result of a precise topographic survey codified on a contour map depicting the landform (Komara, 2009). It is constructed space composed of lawns, shrubs, and woods, $7 \mathrm{~km}$ of paths, a grotto, and waterfalls. Many of the trees found in the park today were planted when the park was created. The area is located at the heart of the park around an artificial lake of 1.5 ha that surrounds a rocky and prominent island with cliffs(hereafter,"around the lake"). The central mountain is a vestige of the old quarry occupying part of the site, which was transformed to resemble a natural landscape. A suspension bridge links the mountain to the surrounding landscape. The lake is surrounded by a $600 \mathrm{~m}$ path that passes through lawns, shrubs, and small woods and ends at a grotto with an imposing waterfall (Muratet et al., 2015).

\subsection{Millenium Park-USA}

The history of Millennium Park is based on the Chicago Plan (1909), which was developed by Burnham and Bennett, one of the pioneers of the Beautiful City Movement, and a connected parking system. The Park was completed in 2004 as a bridge between the past and future of Chicago's city center as part of Grant Park in the Chicago Plan (Metin, 2006; Furnari, 2011; Nurturing Open Space, 2018). The construction of the park, which was started in 1998, is aimed at "fill in the missing piece of Grant Park, attract and sustain the population, revitalize Chicago and stimulate economic growth" (Chen, 2013).

The park, which has one of the largest green roofs in the world and is 24.5 acres, is built on a railway corridor and a 2,200 car parks. There are Bike Station, which allows shopping by bike, the arts, and cultural venues, concert venues, and a solarpowered Welcome Center, as well as there are also important examples of landscape design such as the Pritzker Music Pavilion and BP Pedestrian Bridge (by architect Frank Gehry), The Lurie Garden, The Crown Fountain, and The Cloud Gate. With its innovative architecture, public art and technological wonders, Millennium Park is considered a park of the twenty-first century, but the design of the Park, like Jackson Park and Washington Park (1871 and 1894 by landscape architect Frederick Law Olmsted), also includes natural design and passive recreation goals of 19th-century parks (Flanagan, 2008). Besides, Park, where art and architecture intersect, represents global art in the post-industrial era, which avoids the tendency of modernism to emphasize the expression of the artist (Metin, 2006).

\subsection{Parc de la Villette-France}

Parc de la Villette has become an exemplary open and green space in Paris within the framework of landscape urbanism. Park was used as a meat market and slaughterhouse during III. Napoleon's period, and more than half of the park area, was opened to competition in 1982, has been transformed into a green space by architect Bernard Tschumi. He consciously rejects the "normative" and "traditional" 19thcentury Olmstedian park design, and culture and technology are replaced by nature as the basis of park design (Meyer, 1991). The park has been designed as an open-air cultural center with exhibitions, playgrounds, concert areas, and scientific activity areas. He did this with abstract spatial devices as the system of point, lines, and planes (Cann, 1987).

Parc de la Villette which is described as a 21st century park (Cann, 1987), it is emphasized that landscape should be at the center of urban planning activities to ensure continuity of natural and cultural systems together (Çabuk et al., 2013). Tschumi was influenced by the deconstructivism movement in the project. Due 


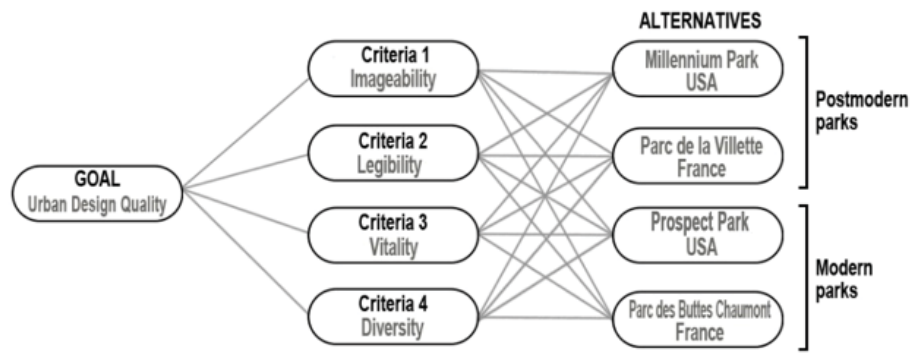

Fig 1. AHP Model Urban Parks Design Quality.

to the risks that future planning may cause with the present data, the park has been designed as an unfinished model where changes can be made, structural elements can be dismantled and reconstructed.

\section{METHOD}

Analytic Hierarchy Process (AHP) was developed by Saaty (1980) to make a choice and prioritization for multi-criteria decision making problems. This is achieved by the evaluation of a set of criteria and sub-criteria through a series of pairwise comparisons. Numerous applications of the AHP have been made since its development and it has been applied to several types of decision problems especially for social sciences (Byun, 2001). In this study, 4 urban parks were defined as alternatives and 4 design qualities were defined as criteria (Figure 1).

Instead of asking urban design criteria such as imageability, legibility, vitality, and diversity to randomly selected people, it is thought that consulting experts will make the study more rational. Firstly, 3 design experts selected the design criteria from the literature those that can be applied to the city parks. Then, the same expert group chose the urban parks that could reflect the traces of modern and postmodern design. Each alternative was compared with each other by another expert panel who were assembled from academia in terms of importance based on these 4 criteria. The scale (Table 3 ) which was formed at this importance level was taken from Saaty (1980). Expert Choice 11 software was used to analyze the data sets.

\begin{tabular}{|c|c|c|}
\hline $\begin{array}{l}\text { Intensity of } \\
\text { Importance }\end{array}$ & Definition & Description \\
\hline 1 & $\begin{array}{r}\text { Equal } \\
\text { importance }\end{array}$ & Both factors are equal in importance \\
\hline 3 & $\begin{array}{l}\text { Moderate } \\
\text { importance }\end{array}$ & $\begin{array}{l}\text { A factor is somewhat more } \\
\text { important than the other according to } \\
\text { experiences and estimations }\end{array}$ \\
\hline 5 & $\begin{array}{l}\text { Strong } \\
\text { importance }\end{array}$ & $\begin{array}{l}\text { A factor is much more important } \\
\text { than the other }\end{array}$ \\
\hline 7 & $\begin{array}{l}\quad \text { Very Strong or } \\
\text { demonstrated } \\
\text { importance }\end{array}$ & $\begin{array}{l}\text { A factor is preferred significantly } \\
\text { much more than the other }\end{array}$ \\
\hline 9 & $\begin{array}{l}\text { Extreme } \\
\text { Importance }\end{array}$ & $\begin{array}{l}\text { One of the factors is absolutely more } \\
\text { important than the others }\end{array}$ \\
\hline $2,4,6,8$ & $\begin{array}{l}\text { Intermediate } \\
\text { values }\end{array}$ & $\begin{array}{l}\text { These are the intermediate values } \\
\text { for the values mentioned above and used } \\
\text { when compromise is needed }\end{array}$ \\
\hline
\end{tabular}

Table 3. The scale of importance (Saaty, 1980). 

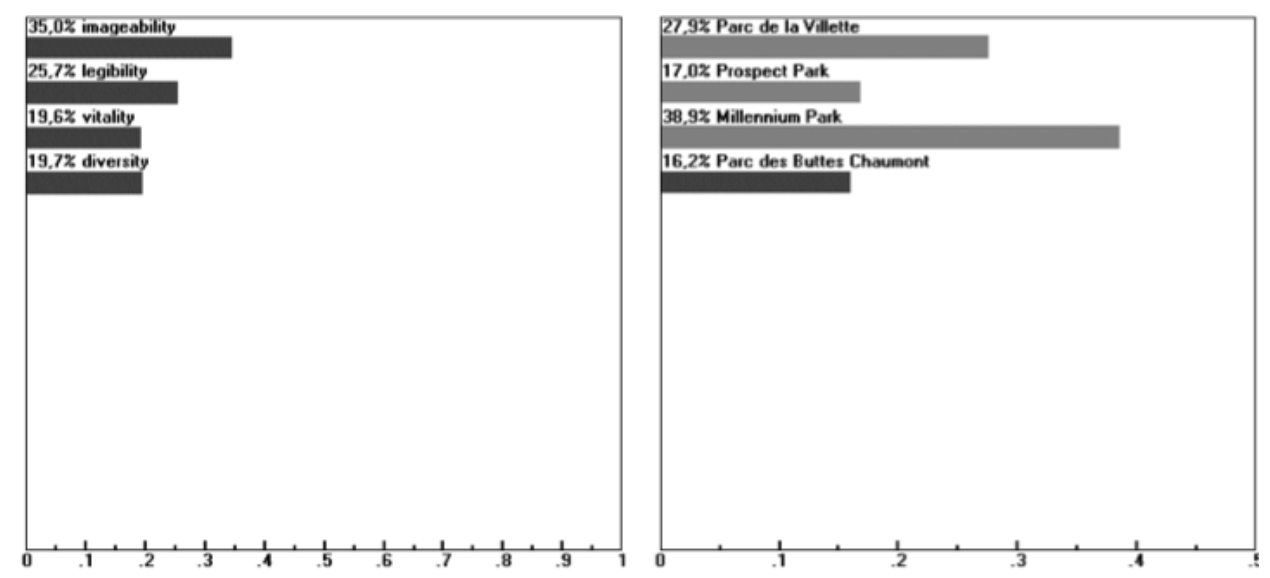

Fig 2. Dynamic Sensitivity Analysis of Design Quality In Parks.

\section{RESULTS AND DISCUSSION}

Sensitivity analysis contributes to verifying the results of the decision. The Expert Choice implementation of AHP produces four graphical sensitivity analysis modes: dynamic, gradient, performance and two-dimensional analysis (Byun, 2001). Dynamic and performance sensitivity analysis are employed in this study. As indicated in Figure 2, according to the evaluation of urban design quality, the degree of priority of the main criteria is shown as follows: Imageability (\% 35), Legibility (\% 25,7), Vitality (\% 19,6), Diversity (\% 19,7). The most important main criterion is the Imageability, while the Vitality is considered the least important. The total consistency rate was recorded as 0,02 and the results were deemed to be consistent since they

were below 0,1 . The fact that imageability is the most important main criterion gains importance in terms of evaluating design quality in parks.

In terms of overall criteria, Millennium Park scored the highest design quality in the result (Figure 3). Millennium Park as a postmodern park has a special character and variety in texture, color and structure type. It was determined that postmodern parks gained higher scores than modern parks in terms of total quality, diversity and imageability criteria. The reason for this may be considered as postmodern design is more widely accepted by experts. Besides, compared to modern design, the postmodern design has more variety and mobility by its nature.

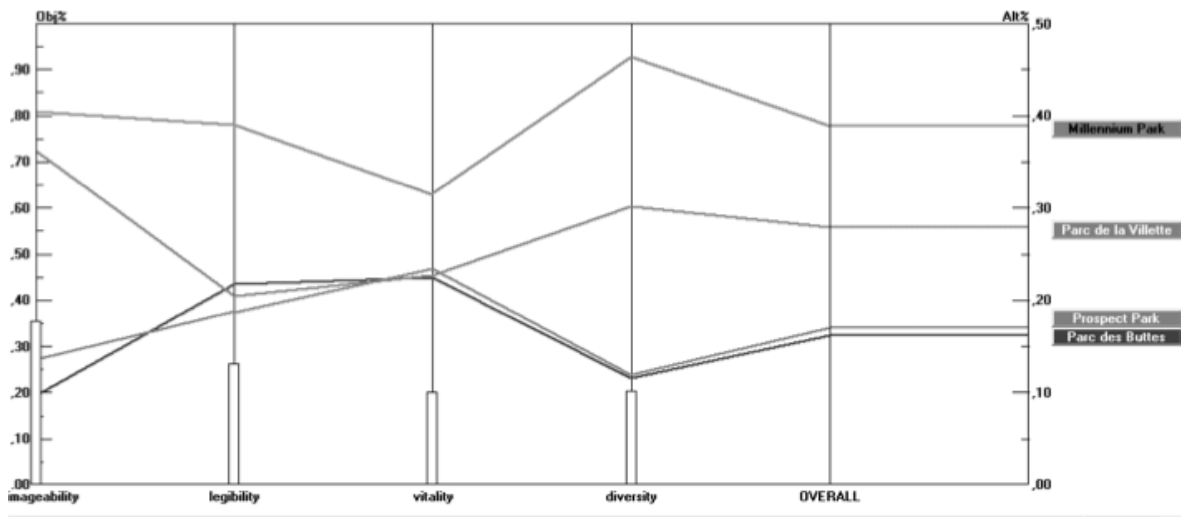

Fig 3. Performance Sensitivity Analysis of Design Quality In Parks. 
Parc de la Villette

Prospect Park

Millennium Park

Parc des Buttes Chaumont
.279

.170

389

.162

Fig 4. Synthesis for Overall Design Quality In Parks.

Parc de la Villette scored the second highest design quality in the result, followed by Prospect Park and Parc des Buttes Chaumont (Figure 4). Parc des Buttes Chaumont as a modern park, it has the lowest design quality. Prospect Park and Parc des Buttes as modern parks offer a uniform layout in terms of park style. Thus, this may have led to a standart perception of the park in terms of design.

As a design quality criterion imageability scored the highest for all study area in the result, followed by legibility (Figure 5 ). Several researchers suggest that imageability also affects other design criteria. (Ewing\&Handy, 2009). Therefore, the imageability can be more prominent than other quality criteria in this study. The fact that the legibility has the highest score after the imageability may be due to the fact that an imageable space is also a legible space.

\section{CONCLUSION}

This study makes a perceptual contribution to the comparison of the design quality of urban parks of different periods. The artistic values and design qualities of architectural structures belonging to the modern and postmodern era have often been the subject of discussion on several platforms and have been studied by many researchers. However, there are very few studies comparing the design quality of city parks which belong to different periods. This study can be regarded as a pioneer in the field, but it also has limitations. It is suggested that future studies will proceed by using a higher number of design quality criteria and taking into account the behavior of park visitors. The results of this study gain importance in terms of revealing the relationship between modern/postmodern processes and design quality. Besides, it is expected that this study could contribute to design and planning disciplines for the determination of spatial strategies of urban parks by identifying problems and to the development of physical features that will improve design quality. 


\section{REFERENCES}

- $\quad$ Aydin, D., \& Ter, U. (2008). Outdoor space quality: Case study of a university campus plaza. International Journal of Architectural Research: ArchNet-IJAR, 2(3), 189-203.

- $\quad$ Barrett, J. L., Hannon, C., Keefe, L., Gortmaker, S. L., \& Cradock, A. L. (2011). Peer Reviewed: Playground Renovations and Quality at Public Parks in Boston, Massachusetts, 1996-2007. Preventing chronic disease, 8(4).

- $\quad$ Bluestone, D. M. (1987). From Promenade to Park: The Gregarious Origins of Brooklyn's Park Movement. American Quarterly, 39(4), 529. doi:10.2307/2713123

- Byun, D. H. (2001). The AHP approach for selecting an automobile purchase model. Information \& Management, 38(5), 289-297.

- $\quad$ Cann, B. (1987). The park of la villette: urban park as building. Places, 4(3).

- $\quad$ Chen, F., (2013). Grant Park Vs. Millennium Park: Evolution Of Urban Park Development. Master Thesis. Department of Landscape Architecture in the Graduate College of the University of Illinois at Urbana-Champaign, USA.

- C C Cabuk, S. N., Çabuk, A., Ersoy, M., Şenöz, E. (2013). Dönüşen peyzaj ve doğa ile tasarım bağlamında peyzaj şehirciliği ve geotasarım kuramları. İçinde Peyzaj Mimarlığı 5. Kongresi Bildiri Kitabı 14-17 Kasım 2013, Adana (ss. 474-487).

- $\quad$ Ewing, R., Handy, S., Brownson, R. C., Clemente, O., \& Winston, E. (2006). Identifying and measuring urban design qualities related to walkability. Journal of Physical Activity and Health, 3(s1), S223-S240.

- $\quad$ Fainstein, S. S. (2005). Cities and diversity: should we want it? Can we plan for it?. Urban affairs review, 41(1), 3-19.

- $\quad$ Flanagan, R. (2008). The Millennium Park Effect. The Practice of Public Art. (pp. 133-151)

- Furnari, S. (2011). Exaptation and Innovation in Architecture: The Case of Chicago's Millennium Park. In: Grandori, A. and Gaillard Giordani, L. (Eds.), Organizing Entrepreneurship. (pp. 37-38). London, UK: Routledge.

- $\quad$ Inceoğlu, M., \& Aytuğ, A. (2009). Kentsel Mekânda Kalite Kavramı. Megaron, 4(3).

- $\quad$ Komara, A.E. 2009. Measure and Map: Alphand's Contours of Construction at the Parc des Buttes Chaumont, Paris 1867. Landscape Journal 28(1):22-39

- Koseoglu, E., \& Onder, D. E. (2011). Subjective and objective dimensions of spatial legibility. Procedia-Social and Behavioral Sciences, 30, 1191-1195.

- $\quad$ Kutay Karaçor,E., Güler,I., Akçam, E. (2019). Evaluation Of Neighborhood Design Quality By Analytic Hierarchy Process. New Horizons in Architecture, Planning and Design. Editor: Latif Gurkan Kaya. ISBN: 978-605-8022-90-4. Gece Publishing.

- $\quad$ Lancaster, C. (1972). Prospect Park Handbook. New York, NY: Long Island University Press

- $\quad$ Lynch, K. (1960). The image of the city (Vol. 11). MIT press.

- Meyer, E. K. (1991). The Public Park as Avante-Garde (Landscape) Architecture: A Comparative Interpretation of Two Parisian Parks, Parc de la Villette (1983-1990) and Parc des Buttes-Chaumont (1864-1867). Landscape Journal, 10(1), 16-26. doi:10.3368/lj.10.1.16

- Metin, S., (2006).Public Space in the Millennium: Case Study of Millennium Park, Chicago, IL. Master Thesis, Master of Community Planning in the School of Planning of the College of Design, Art, Architecture, and Planning, USA.

- Montgomery, J. (1998). Making a city: Urbanity, vitality and urban design. Journal of urban design, 3(1), 93-116.

- $\quad$ Muratet, A., Pellegrini, P., Dufour, A.-B., Arrif, T., \& Chiron, F. (2015). Perception and knowledge of plant diversity among urban park users. Landscape and Urban Planning, 137, 95-106.

- Nurturing Open Space 2018, Viewed 03 November 2019, <http://burnhamplan100.lib.uchicago.edu/newberryexhibit/ nurturing/parks-preserves.shtml>.

- $\quad$ Özyavuz, M, Korkut, A . (2016). Reflections Of Cultural Diversity In Turkey Urban Parks And Green Areas: Istanbul, Tekirdag, Kırklareli Examples. İn̈nü Üniversitesi Sanat ve Tasarım Dergisi, 6 (13) , 0-0

- $\quad$ Patton, G. E., \& Menke, W. F. (1982). Design with nature and culture: The Long Meadow, Prospect Park, Brooklyn, New York as exemplar of an urban park compatible with its past. The Journal of Garden History, 2(4), 361-376. doi:10.1080/01445170. 1982.10412417

- $\quad$ Prospect Park Alliance. (2013). About Prospect Park. www.prospectpark.org/ about

- Saaty, T. L. (1980). The Analytic Hierarchy Process. Mc-Graw-Hill New York. Agricultural Economics Review, 70 
- Strohmayer, U. (2006). Urban design and civic spaces: nature at the Parc des Buttes-Chaumont in Paris. Cultural Geographies, 13(4), 557-576. doi:10.1191/1474474006cgj375oa

- Sugiyama, T., Gunn, L. D., Christian, H., Francis, J., Foster, S., Hooper, P., ... \& Giles-Corti, B. (2015). Quality of public open spaces and recreational walking. American journal of public health, 105(12), 2490-2495.

- Taylor, B. T., Fernando, P., Bauman, A. E., Williamson, A., Craig, J. C., \& Redman, S. (2011). Measuring the quality of public open space using Google Earth. American journal of preventive medicine, 40(2), 105-112.

- Toth, E. (1995). The Public Garden: Managing Urban Woodlands. The Journal of the American Association of Botanical Gardens and Arboreta 10:14-17 